\title{
The ASEAN Economic Community and the East Asian agenda ${ }^{1}$
}

\section{Somkiat Tangkitvanich and Saowaruj Rattanakhamfu}

\section{The gap in East Asian integration}

Economic integration through international trade and foreign direct investment (FDI) brings about economic prosperity by enabling the greater division of labour, which, in turn, facilitates more efficient resource allocation and improves productivity through competition.

The level of economic integration in East Asia is quite high-nearly half (47.2 per cent) of all the trade and over half (53.9 per cent) of all outward FDI in East Asia is intra-regional (see Figure 7.1). The two sub-regions of East Asia, North-East Asia and South-East Asia, are closely linked to each other through trade and direct investment. In fact, the linkages between the two sub-regions are stronger than those within the sub-regions.

1 A draft version of this paper was presented at the 38th PAFTAD Conference in November 2016 and revised in January 2017. Some details may have changed due to events between the time of writing and the time of publication. 
(a) Trade

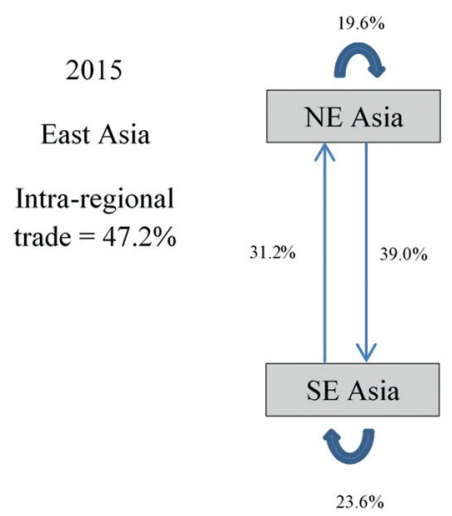

(b) Outward FDI

\section{2}

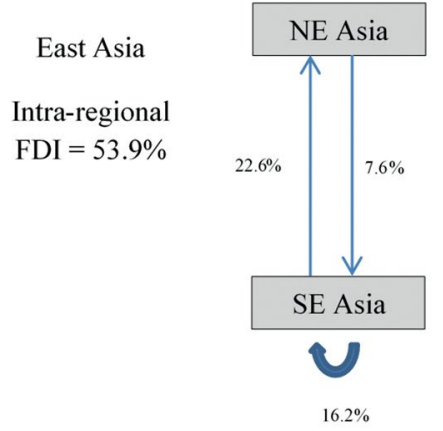

Figure 7.1: Intra-regional trade and foreign direct investment in East Asia (unit: per cent of total)

Source: Authors. Data from the Asian Development Bank's Asia Regional Integration Center.

From a broader perspective, the level of intra-regional trade in East Asia (as a share of total regional trade) is lower than that of the EU but higher than that of North America (the US and Canada). Adjusted for the different trade volumes of each region, the intra-regional trade intensity index for East Asia was 1.66 in 2015, lower than those for the EU (1.98) and North America (1.78). ${ }^{2}$ This reflects two important facts.

First, East Asia not only trades intra-regionally but also maintains strong linkages with the rest of the world. Although the intra-regional trade share in East Asia increased slightly during 1995-2015 from 45.0 to 47.2 per cent, the region maintains strong trade linkages with the outside world via a well-known triangular trade structure (see Figure 7.2); production occurs within the region but final goods are then exported out of the region.

2 The intra-regional trade intensity index is the ratio of the intra-regional trade share to the share of world trade with the region, calculated using trade data. It is computed as $\left(\mathrm{T}_{i i} / \mathrm{T}_{i}\right) /\left(\mathrm{T}_{j} / \mathrm{T}_{w}\right)$, where $\mathrm{T}_{i i}$ is exports of region $i$ to region $i$ plus imports of region $i$ from region $i, \mathrm{~T}_{i}$ is total exports of region $i$ to the world plus total imports of region $i$ from the world, $\mathrm{T}_{j}$ is total exports of region $j$ to the world plus total imports of region $j$ from the world and $\mathrm{T}_{w}$ is total world exports plus imports. The index determines whether trade within the region is greater or smaller than should be expected on the basis of the region's importance in world trade. An index of more than one indicates that trade flow within the region is larger than expected, given the importance of the region in world trade (for more details, refer to aric.adb.org/integrationindicators/technotes). 

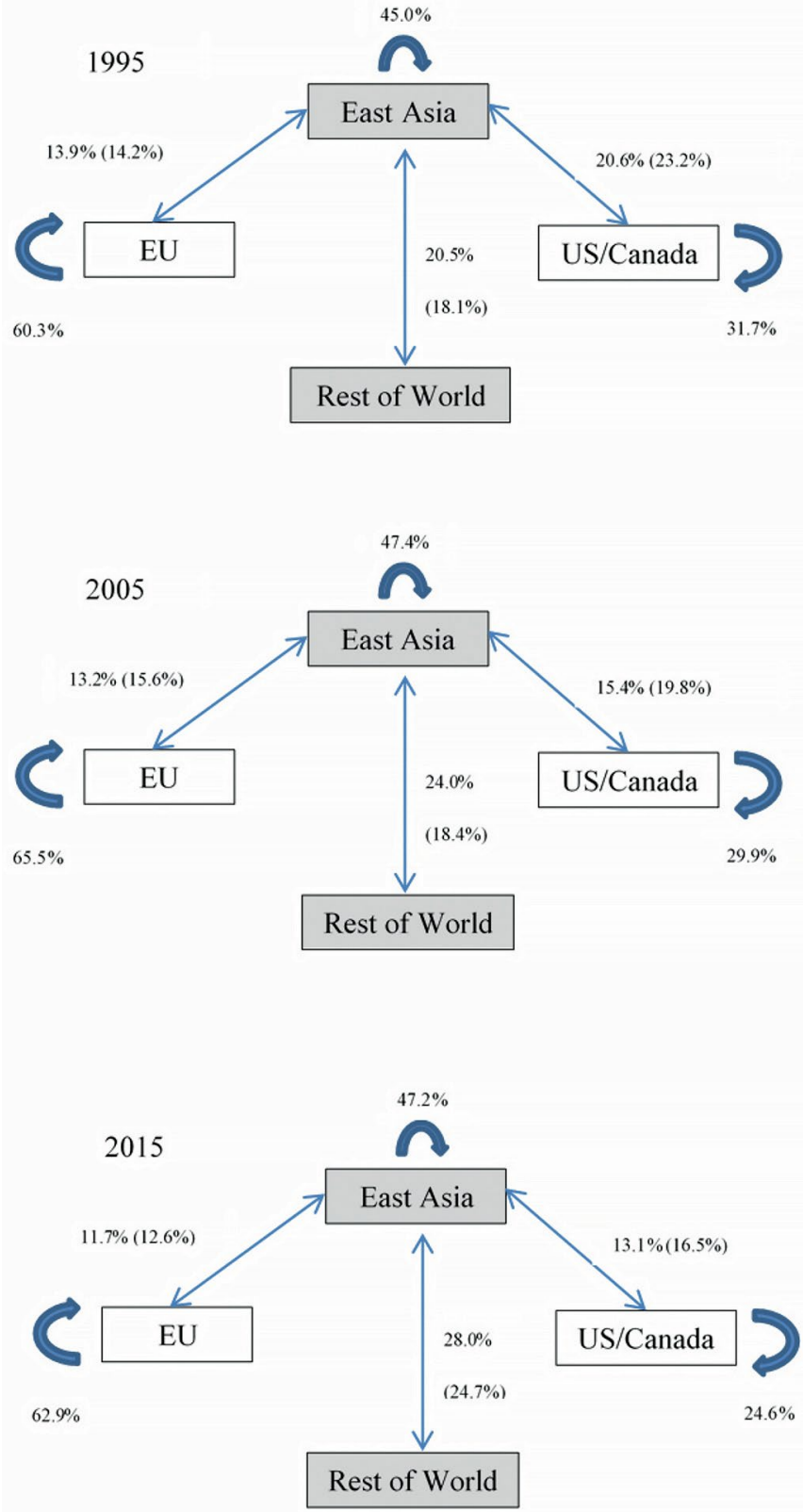

Figure 7.2: Shares of intra-regional trade in East Asia and inter-regional trade linkages between East Asia and the world

Note: The numbers in parentheses are trade shares from the perspectives of East Asia's trading partners.

Source: Authors. Data from the Asian Development Bank's Asia Regional Integration Center. 
Second, if East Asia reduces trade barriers within the region, it will provide more room for intra-regional trade expansion. Without further progress on liberalisation through the World Trade Organization, the only option to expand trade in the region is through unilateral, bilateral or regional action with other countries in the region. East Asia is still in the early stages of forming free trade agreements (FTAs); therefore, there is great potential for intra-regional trade expansion.

North-East Asia still has only one FTA, the China - South Korea FTA. China became South Korea's largest trading partner in 2004, but the FTA only came into effect in late 2015 and it is still viewed as rather shallow (Schott \& Jung, 2015). The negotiations for a trilateral FTA between China, Japan and South Korea, launched in 2012, have made minimal progress because of political tensions between Japan and the other two countries.

South-East Asia appears to have made more progress on FTAs, including through the Association of Southeast Asian Nations (ASEAN) Free Trade Area (AFTA), which was implemented in 1993, and the AEC, which was officially launched in late 2015. However, the AEC implementation is behind schedule, as discussed in the next section.

A mega-FTA negotiation launched in 2013 under the name of the Regional Comprehensive Economic Partnership (RCEP) involves an effort to integrate North-East Asia, South-East Asia and three other major trading partners. RCEP negotiations were scheduled to be finalised by 2016 but the negotiation progress is lagging far behind schedule. Meanwhile, the Trans-Pacific Partnership (TPP), which encompasses 12 countries in East Asia and the Pacific, was concluded in late 2015. However, it is unlikely to come into effect under Donald Trump's Presidency in the US.

The delay in formally integrating East Asia through FTAs means that a large portion of intra-regional trade occurs outside the preferential treatment and protection offered by FTAs, exposing it to existing barriers and possible future protectionism. Table 7.1 provides a rough estimate of the ratio of intra-regional trade uncovered by any FTAs for the ASEAN+3 and the ASEAN+6 regions. The estimation, shown in column (3), is obtained by subtracting the ratio of intra-regional trade covered by FTAs, proxied by the ratio of trade between existing FTA partners in column (2), from the ratio of intra-regional trade in column (1). 
Table 7.1: Intra-regional trade with free trade agreement partners and non-partners to total trade in 2015

\begin{tabular}{|l|c|c|c|l|}
\hline $\begin{array}{l}\text { Region/ } \\
\text { country }\end{array}$ & $\begin{array}{c}\text { Intra-regional } \\
\text { trade to total } \\
\text { trade (1) }\end{array}$ & $\begin{array}{c}\text { Intra-regional } \\
\text { trade with FTA } \\
\text { partners to } \\
\text { total trade (2) }\end{array}$ & $\begin{array}{c}\text { Intra-regional } \\
\text { trade with non-FTA } \\
\text { partners to total } \\
\text { trade (3)=(1)-(2) }\end{array}$ & $\begin{array}{l}\text { Countries in the } \\
\text { region that are } \\
\text { not FTA partners }\end{array}$ \\
\hline ASEAN+3 & $47.2 \%$ & & & None \\
\hline ASEAN & $54.8 \%$ & $54.8 \%$ & $0.0 \%$ & Japan \\
\hline China & $26.3 \%$ & $19.1 \%$ & $7.2 \%$ & China/Korea \\
\hline Japan & $41.9 \%$ & $15.2 \%$ & $26.7 \%$ & Japan \\
\hline Korea & $43.7 \%$ & $36.3 \%$ & $7.4 \%$ & None \\
\hline ASEAN+6 & $48.7 \%$ & & & India \\
\hline ASEAN & $60.3 \%$ & $60.3 \%$ & $2.0 \%$ & Japan/India \\
\hline Australia & $64.4 \%$ & $61.5 \%$ & $9.3 \%$ & $\begin{array}{l}\text { China/Australia/ } \\
\text { New Zealand }\end{array}$ \\
\hline China & $31.1 \%$ & $21.8 \%$ & $12.7 \%$ & $\begin{array}{l}\text { China/Korea/ } \\
\text { New Zealand }\end{array}$ \\
\hline India & $27.7 \%$ & $15.0 \%$ & $27.1 \%$ & Japan \\
\hline Japan & $47.0 \%$ & $19.9 \%$ & $7.40 \%$ & India/Japan \\
\hline Korea & $48.5 \%$ & $41.1 \%$ & $26.0 \%$ & \\
\hline New Zealand & $56.4 \%$ & $30.4 \%$ & & \\
\hline
\end{tabular}

Source: Authors' calculations based on data from the Asian Development Bank's Asia Regional Integration Center.

The table shows that a significant portion of intra-regional trade is not covered by trade agreements that protect against current and possible future protectionism. This is especially true for Japan, which has the highest ratios of intra-regional trade uncovered by any FTAs in both the ASEAN+3 and the ASEAN+6 groups, with ratios of 26.7 and 27.1 per cent, respectively. For the ASEAN+6 group, India has the second highest ratio of intra-regional trade uncovered by any FTAs at 12.7 per cent, as well as the lowest ratio of intra-regional trade at 27.7 per cent. As ASEAN has formed FTAs with all trading partners in ASEAN+3 and ASEAN+6, all of its intra-regional trade is covered by at least one FTA.

It should be noted that Table 7.1 overestimates the ratio of intra-regional trade protected by FTAs in many ways. Most importantly, most FTAs have exempted certain products from tariff reductions through lists of sensitive products that are subject to later liberalisation or possible trade remedies. Even products that are subject to tariff reductions can still face 
costly rules of origin (ROOs) and discriminatory non-tariff measures (NTMs). Nevertheless, Table 7.1 provides a useful snapshot of the current state of trade liberalisation in East Asia. It confirms that East Asia has a good deal of room for intra-regional trade expansion through tighter economic integration.

The objectives of this chapter are threefold. First, the chapter aims to assess the progress of regional integration in East Asia, with a focus on ASEAN. Second, it aims to analyse the prospects of deepening regional integration through ASEAN, RCEP and the TPP, and to propose some recommendations on further regional integration. Finally, the chapter draws some policy implications for Thailand, many of which should be useful to other ASEAN countries.

\section{ASEAN economic integration: The state of play}

ASEAN announced the official launch of the AEC in late 2015 and, in 2017, it celebrated its 50th anniversary. Although ASEAN has realised some political achievements during the past five decades, its economic integration project remains very much a work in progress, and it is expected to remain so for many years, or even decades, to come. The term 'Community' (the ' $\mathrm{C}$ ' in AEC) is a misleading description of ASEAN's economic integration goals. The term connotes the idea of supranationality, which has never been on the negotiation agenda among ASEAN members, except in very limited dimensions (Kausikan, 2016).

The ASEAN Secretariat claims that the implementation of the AEC Blueprint 2015-the AEC's foundational strategic document-has been substantively achieved in many areas, including in eliminating tariffs, facilitating trade, advancing the services liberalisation agenda, liberalising and facilitating investment and facilitating skilled labour mobility (ASEAN Secretariat, 2015a). As a result, the AEC scorecard (ASEAN Secretariat, 2015b) claimed a high reported completion rate (see Figure 7.3). However, these claims are far from convincing. Some argue that the uncompleted issues are by far the more important ones. In addition, the AEC scorecard measures the implementation of milestones and priority actions identified in the AEC Blueprint 2015. In other words, it measures the means, rather than the ends, of the AEC (Menon \& Melendez, 2015). 


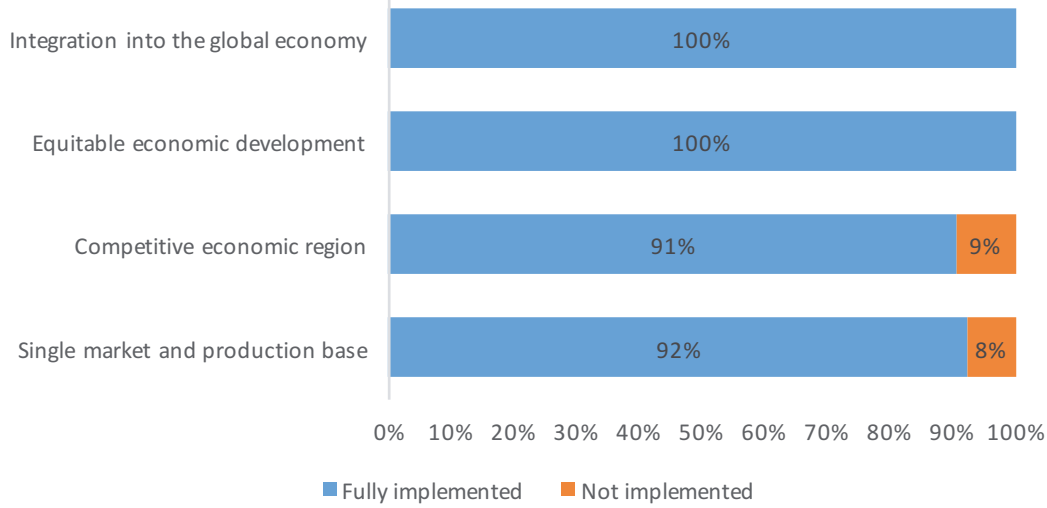

Figure 7.3: ASEAN Economic Community (AEC) scorecard measures, fully implemented ASEAN-wide and high-priority measures, by AEC Pillar, 2008-2015: Number of measures (as of 31 October 2015)

Source: ASEAN Secretariat (2015b).

In fact, levels of integration vary greatly by sector (see McKinsey 2014). The only clear success that ASEAN can claim is the reduction of tariffs among member countries. Since the implementation of the Common Effective Preferential Tariff (CEPT) agreement as part of the AFTA in the 1990s, tariff rates on about 99 per cent of AFTA countries' product items have been reduced to zero. The new ASEAN members-Cambodia, Laos, Myanmar and Vietnam (CLMV) - have reduced their tariffs to the range $0-5$ per cent for 93 per cent of their product items. As a result, average CEPT tariff rates in ASEAN countries now stand at 0.04 per cent for the original ASEAN members (ASEAN-6, i.e. Indonesia, Malaysia, the Philippines, Singapore, Thailand and Brunei) and 1.33 per cent for CLMV (see Figure 7.4).

The ROOs under ASEAN are relatively simple and transparent, either requiring 40 per cent regional value added or the 'change of tariff heading' method. The latter involves examining the intermediate goods that make up a final product, and noting whether changes in tariff classification have occurred in the transformation. In many cases, businesses have options to use either rule to qualify for preferential treatment under AFTA. According to Cadot and Ing (2016), the simple average ad valorem equivalent of ASEAN's ROOs is estimated to be 3.4 per cent across all sectors and the trade-weighted average is estimated to be 2.1 per cent. Thus, the ASEAN ROOs do not appear to be overly restrictive. However, the restrictiveness differs from sector to sector. In particular, ASEAN ROOs are less restrictive 
in sectors such as electronics and capital equipment, but more restrictive in sectors such as leather products, textiles and apparel, footwear, and automobiles.

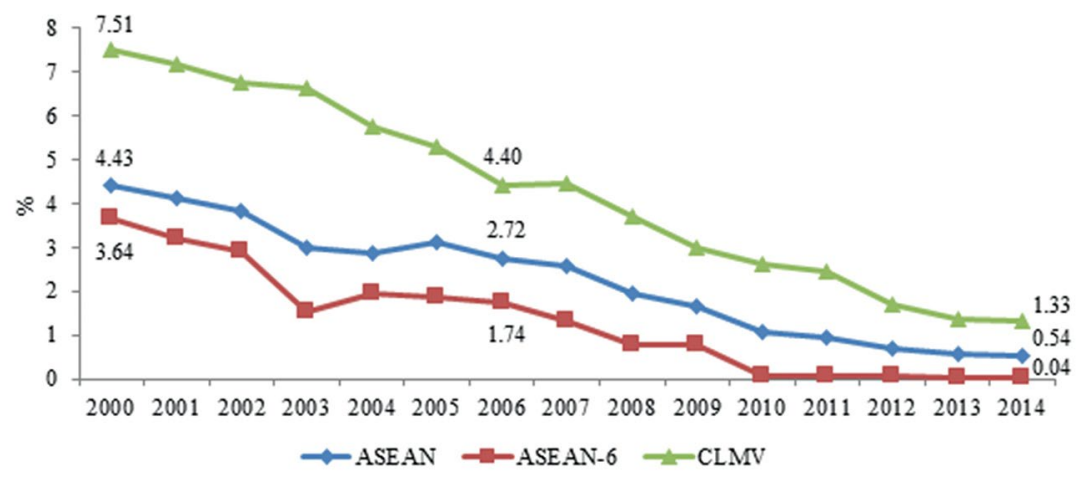

Figure 7.4: Average Common Effective Preferential Tariff rates in ASEAN countries, 2000-14

Source: Compiled using data from OECD (2016).

The free flow of goods among ASEAN member countries continues to be hindered by the prevalent use of NTMs. Although the average tariff rates of ASEAN countries decreased from 8.9 per cent in 2000 to 4.5 per cent in 2015, the number of NTMs increased from 1,634 to 5,975 over the same period (Ing, de Cordoba \& Cadot, 2016). These NTMs may have adverse consequences for the sourcing decisions of firms, the structure of trade and the structure of related industries. In addition, the increase in NTMs may explain the slow rise of intra-ASEAN trade (Cadot \& Ing, 2016). The extent and nature of NTM usage differs across sectors and ASEAN countries (Thailand Development Research Institute [TDRI], 2013; Cadot \& Ing, 2016).

TDRI (2013) found large variations in the use of NTMs among ASEAN countries. For example, Singapore applies fewer NTMs than other ASEAN countries. The measures that it does apply are reasonably transparent and non-discriminatory, aiming primarily to protect Singapore's consumers and the environment. Conversely, countries such as Indonesia and Malaysia that have active industrial policies apply more NTMs. Some NTMs are marked 'red' by the Coordinating Committee on ASEAN Trade in Goods Agreement (CCA), indicating that they are 'core NTMs', also known as non-tariff barriers (NTBs). These include non-automatic licensing, quantitative restrictions, prohibitions, 
enterprise-specific restrictions, single channels for imports and foreign exchange market restrictions. For example, car assemblers in Thailand have long complained about Malaysia's import licensing system that allows only domestic car producers to import cars into the country, thus discriminating against foreign automakers. A study by the Economic Research Institute for ASEAN and East Asia (ERIA, 2012) confirmed that Indonesia and Malaysia have the highest incidence of NTBs, whereas Thailand and the Philippines have the least (see Figure 7.5).

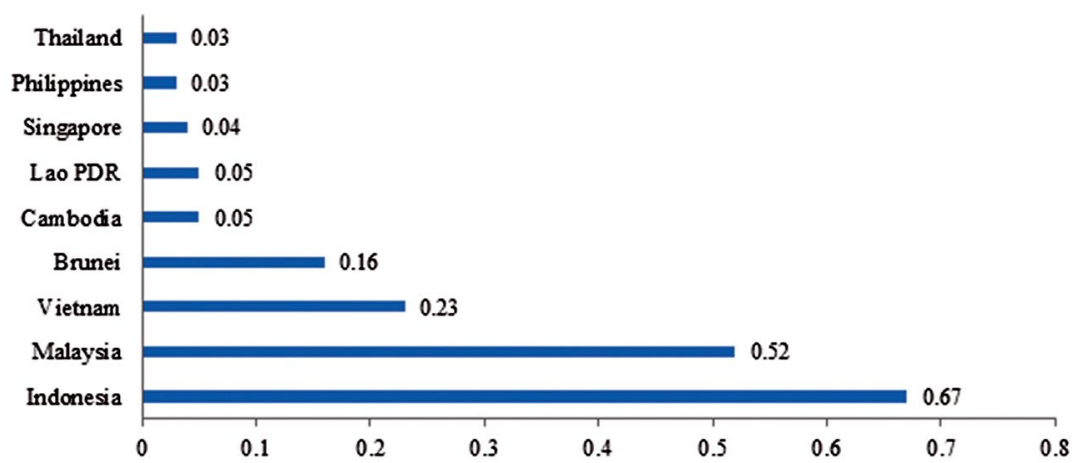

Figure 7.5: Core non-tariff measures restrictiveness index in ASEAN, 2009 Note: Higher numbers indicate greater restrictions.

Source: Compiled using data from ERIA (2012).

Although minimising NTBs is an action target in the AEC Blueprint, ASEAN has relied on a voluntary approach to reduce them, with very limited success. A study by TDRI (2013) examined its lack of success. First, information on existing NTMs is not fully available or easily accessible. This is because the use of NTMs is scattered among many agencies and often embedded in executive decrees, regulations or announcements that are available only in local languages. More importantly, under the voluntary approach, member countries may have incentives to underreport the NTBs that they are using. Second, there is no effective monitoring system to keep track of changes in NTMs among member countries. Third, ASEAN has no power to compel its members to revise NTMs that are found to be non-transparent or to eliminate the measures identified as NTBs.

High trade costs associated with moving goods and services across borders are another factor hindering intra-regional trade. Intal (2015a) reviewed the state of trade facilitation initiatives in ASEAN countries. 
The review focuses on customs modernisation, the national 'single window' system (which allows trading parties to lodge all information required by regulators at a single national entry point) and national trade repositories (online references with comprehensive information on each country's tariffs and NTMs). He found that, although there has been significant progress in trade facilitation in the region in recent years, there remains a huge gap among member countries. The gap seems to be correlated with the overall development gap. The main challenges in trade facilitation in ASEAN include inadequacy of funds, availability of technical talent, the technical infrastructure of the system and coordination issues among related agencies.

Another study by the World Economic Forum (2013) found that most ASEAN members, with the exception of Singapore, perform poorly in terms of efficiency and transparency of border administration. Thus, the ASEAN Single Window (ASW) has been established to link national customs and trade regimes. However, only the original ASEAN members and Vietnam are ASW-ready.

Further, the level of investment liberalisation in ASEAN is different across countries and sectors. Intal (2015b) measured the level of foreign investment liberalisation under the ASEAN Comprehensive Investment Agreement. He used a weighted average of the foreign equity liberalisation rate and the liberalisation rate of other investment restrictions-namely, restrictions on national treatment and other market access restrictions. He found that the level of investment liberalisation was high in manufacturing, with the exceptions of Indonesia and Vietnam. In contrast, the level of liberalisation in the agriculture and mining sectors varied greatly across ASEAN, with some countries being very open and allowing foreign investment participation and others being more restrictive.

ASEAN has been negotiating service liberalisation since the creation of the ASEAN Framework Agreement on Services (AFAS) in 1996. The AEC Blueprint has established clear liberalisation targets to substantially remove all restrictions on trade in services for four priority service sectors: air transport, e-ASEAN (information and communication technologies), health care and tourism-the latter by 2010 and all other sectors by 2015. Milestones for progressive liberalisation are marked by a gradual increase in ASEAN equity participation in various service sectors. 
7. THE ASEAN ECONOMIC COMMUNITY AND THE EAST ASIAN AGENDA

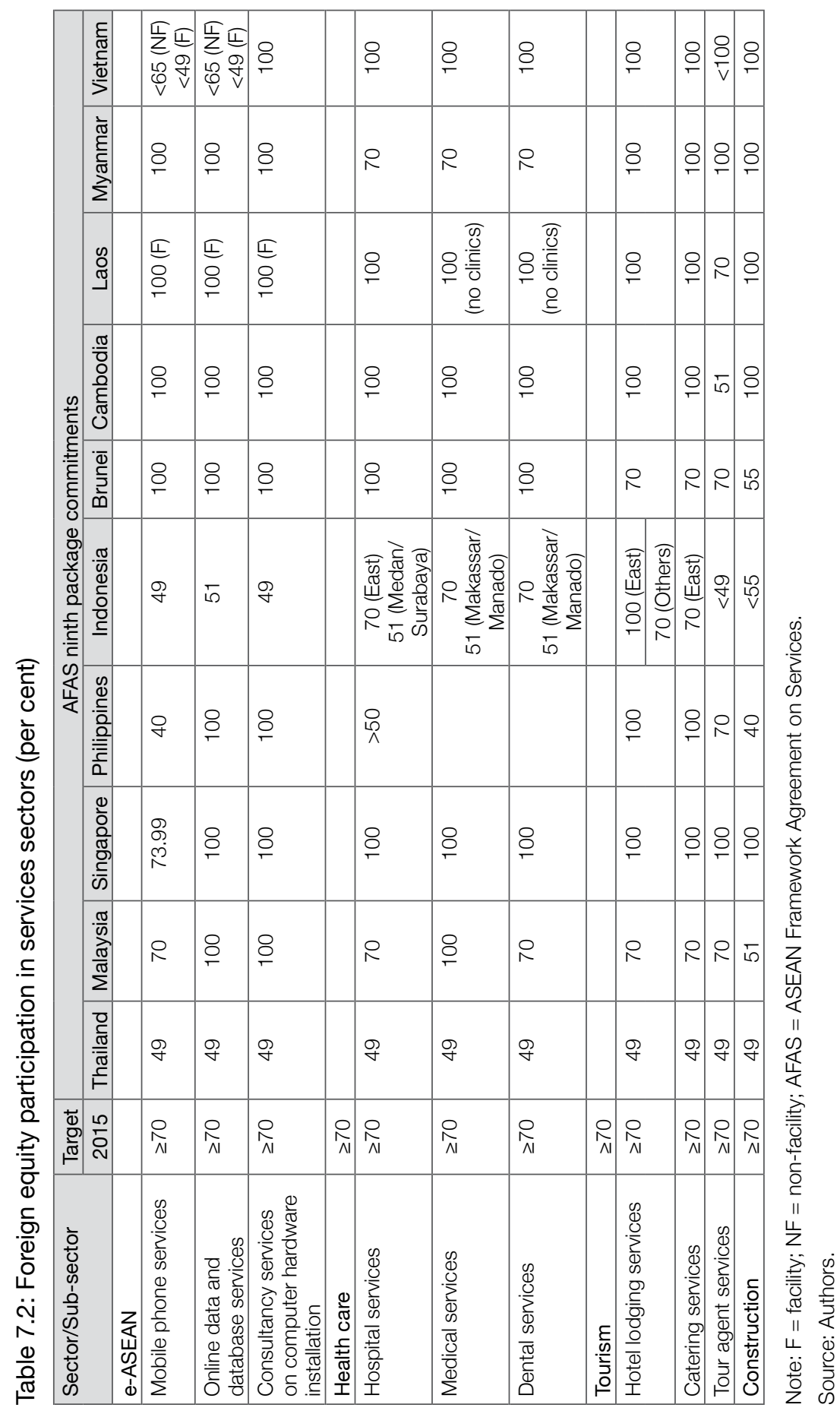


However, some ASEAN countries, especially Thailand, the Philippines and Indonesia, were not able to meet these targets by the 2015 deadline (see Table 7.2). The World Bank (2011) found that service trade restrictions were higher in more developed countries, such as the Philippines, Indonesia and Thailand, and lower in less developed countries, such as Cambodia and Vietnam (see Figure 7.6). The lower restrictiveness in the latter group may be the result of an underdeveloped regulatory regime in these countries (World Bank, 2013) or a lack of domestic providers with vested interests. The resistance of more developed ASEAN countries to service liberalisation is clearly shown in Indonesia and Thailand's specific commitments under the latest (2015) ninth package of commitments (see Table 7.3). Table 7.3 clearly indicates that, although more service sub-sectors are nominated for liberalisation in the ninth package, many commitments are inconsequential or worthless.

Table 7.3: Some commitments of Indonesia and Thailand under the AFAS ninth package

\begin{tabular}{|l|}
\hline Indonesia's commitments \\
\hline CPC 832 Other rental services, limited to video tape rental services \\
CPC 873 Investigation and security, limited to shoplifting investigation services \\
CPC96321 Museum services limited to museums of jewellery \\
CPC 71224 Passenger transportation by man or animal-drawn vehicles \\
CPC 71236 Freight transportation by man or animal-drawn vehicles \\
\hline Thailand's commitments \\
\hline CPC 64340 Bicycle courier service for food delivery \\
CPC 93321 Day care services for children with disabilities \\
CPC 66300 Transport service via space, including space passenger transportation \\
service (excluding launching and placing of satellites in space) \\
Railway car cleaning service
\end{tabular}

Note: AFAS = ASEAN Framework Agreement on Services; CPC = Central Product Classification.

Source: Authors. Data from countries' specific commitments under AFAS ninth package.

Narjoko (2015) examined the progress of liberalisation in the AFAS by measuring changes in the rate of liberalisation of the AFAS commitments between the seventh package, concluded in 2009, and eighth package, concluded in 2010 . He found a marginal improvement only in the depth of services liberalisation rate between the two packages, although there were significant increases in the number of sub-sectors covered in the eighth package. Analysing the changing liberalisation rates across the member states, he found that the offers became more liberal only in Brunei Darussalam, Cambodia, Malaysia and Singapore, whereas decreases were recorded for the other member states. 


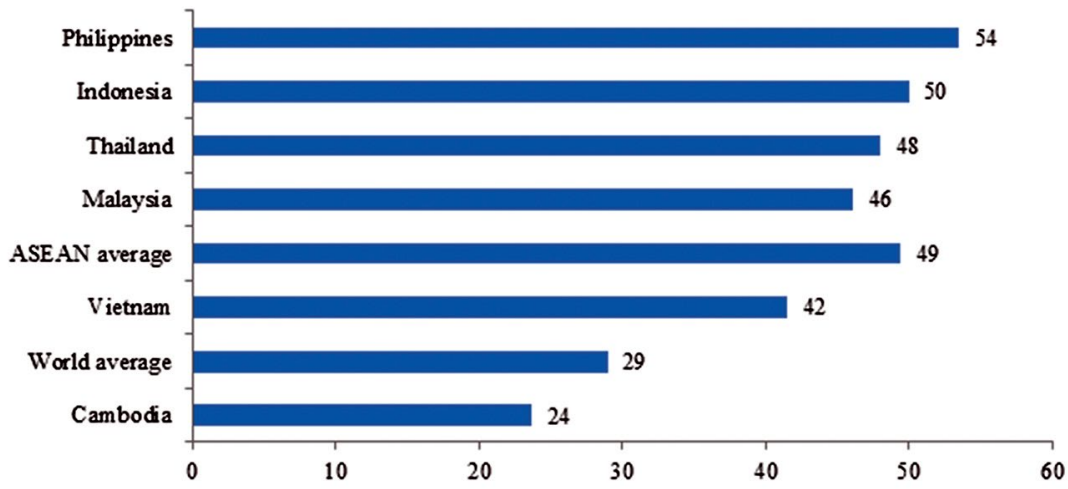

Figure 7.6: Overall services trade restrictiveness index in ASEAN, 2008-11 Note: A higher number indicates greater restrictions.

Source: Compiled using data from World Bank (2011).

Progress in trade liberalisation efforts has been extremely slow over the last 20 years. Although concrete quantitative liberalisation goals have been set, the AEC Blueprint allows for flexibility in attaining such goals, as follows (Nikomborirak, 2013):

- If a member country is not able to meet the parameters of commitments set in the previous round, it may catch up in the next round.

- If a member country is not able to make commitments on liberalising agreed sub-sectors, it is permitted to substitute sub-sectors outside the list of agreed sub-sectors.

- Liberalisation through the 'ASEAN minus X' formula is permitted; under this rule, if a member country cannot meet the liberalisation target, the remaining member countries may proceed to implement the liberalisation measure among themselves.

According to Nikomborirak (2013), these flexibility provisions are inconsistent with ASEAN's liberalisation goals. First, the AEC Blueprint stipulates that there shall be no 'backloading' of commitments; however, allowing countries to catch up on commitments in following rounds would undoubtedly lead to such a problem. Second, allowing a member country to substitute priority service sub-sectors scheduled for early liberalisation with other non-priority sub-sectors would render the specification of priority sectors meaningless. Finally, the option of liberalisation through the 'ASEAN minus $\mathrm{X}$ ' formula dilutes what are meant to binding commitments to 'best effort' commitments. 
Moreover, service liberalisation under ASEAN contains no commitment to address behind-the-border issues, such as interconnection for telecom services or access to ATMs for banking, which are crucial to the creation of effectively competitive markets. The difference in laws and regulations among member countries is also problematic. As a result, service liberalisation under ASEAN in its current form would not create a single service market. For example, data localisation regulation in Indonesia requires 'electronic system operators for public service', a broad and undefined group of companies, to establish data and disaster recovery centres in Indonesia for the purpose of law enforcement and data protection. Vietnam requires that all organisations establishing websites or social networks establish at least one server inside the country that contains the entire history of information posted and shared (Bauer, Makiyama, van der Marel \& Verschelde, 2014). Nazir Razak, the chairman of Malaysia's CIMB Group Holdings and a co-chairman of the ASEAN Business Club, has commented that CIMB cannot establish a centralised back office operation because of the differences in national laws, despite having a significant presence in Malaysia, Indonesia, Thailand and Singapore (Tan, 2016).

ASEAN's aim is to achieve financial and capital market integration through financial services liberalisation, capital account liberalisation and capital market development. However, even banking integration, the area making the most progress, has advanced very slowly so far (Asian Development Bank, 2013; Almekinders, Fukuda, Mourmouras, Zhou \& Zhou, 2015). This is partly because the level of financial development varies greatly among ASEAN countries. Financial integration in ASEAN will be a long-term project, given the flexibilities permitted, such as the 'ASEAN minus X' formula, and the ability for ASEAN members to set their own conditions and timelines for liberalisation. Nevertheless, ASEAN has been successful in setting up a macro-economic surveillance mechanism through the ASEAN+3 Macroeconomic Research Office and a regional financial safety net through the Chiang Mai Initiative Multilateralization (ERIA, 2012).

In promoting cross-border movement of labour, ASEAN has also achieved very little. From an economic development perspective, the opening up of unskilled labour markets through FTAs would be a beneficial policy option, given the relative abundance of unskilled labour in many ASEAN countries. However, the AEC Blueprint attempts to facilitate 
only the mobility of skilled professionals, currently comprising just eight professions-engineers, physicians, dentists, nurses, architects, surveyors, accountants and tourism professionals. This excludes, among others, senior staff at regional banks, telecom operators and other service providers. It shows that service liberalisation under the AEC Blueprint 2015 Mode 3 (services delivered through commercial presence) and Mode 4 (services delivered through the presence of a natural person) are not linked.

To facilitate the movement of the aforementioned professionals, ASEAN has adopted an approach involving mutual recognition arrangements (MRAs). However, the arrangement is considered to represent, at most, partial recognition, as noted by the Organisation for Economic Co-operation and Development (OECD, 2016). Under the MRA scheme, ASEAN professionals intending to work in other member countries are required to comply with the domestic regulations of host countries under the same pre-existing conditions. In the case of Thailand, for example, the requirements imposed on ASEAN professionals are the same as those imposed on professionals from the non-ASEAN countries. For instance, a requirement to pass an examination conducted in the Thai language is applied in medical professions to block the professional mobility of foreign practitioners. Many ASEAN countries impose similar requirements.

Moreover, for professional services, such as engineering and architectural services, policies applied in some countries are far more liberal than the MRA regime. As a result, even if there are signed MRA agreements, professionals have little incentive to use them because existing regulations are more liberal. In summary, the movement of professionals under the AEC continues to face as many hurdles as ever. Unsurprisingly, the uptake of the scheme has been low. In practice, many professionals choose to work in other ASEAN countries by registering themselves as consultants (Fukunaga, 2015).

Our review of the progress of trade and investment liberalisation in ASEAN in this section shows that, although there has been some limited tangible progress towards the goals of regional integration, to date, actual implementation continues to lag far behind the targets set in the AEC Blueprint 2015. 
Despite this, ASEAN has declared that its regional integration project has been successful, claiming accomplishments in:

Eliminating tariffs and facilitating trade; advancing the services trade liberalization agenda; liberalizing and facilitating investment; streamlining and harmonizing capital market regulatory frameworks and platforms; facilitating skilled labor mobility; promoting the development of regional frameworks in competition policy, consumer protection and intellectual property rights; promoting connectivity; narrowing the development gap; and strengthening ASEAN's relationship with its external parties. (ASEAN Secretariat, 2015a)

Despite these claims of success, which are made in the opening pages of the AEC Blueprint 2025, the proceeding item is a call for ASEAN countries to finish all remaining unimplemented works. Like the 2015 version, the aspirations of the AEC Blueprint 2025 are to create a deeply integrated and highly cohesive economy, engender inclusive growth, foster robust productivity growth, promote good governance, widen connectivity and reinforce ASEAN centrality in the emerging regional economic architecture. However, the AEC Blueprint 2025 does not clarify how future implementation efforts will improve on past efforts.

To critical observers, ASEAN integration has so far produced very few tangible results. For example, Elms (2016a) concluded that 'ASEAN officials shifted the rhetoric as the deadline loomed to argue instead that the AEC itself should be viewed as process and not a destination'. The Economist commented mockingly that 'when it comes to elevating form over substance, and confusing a proliferation of meetings and acronyms for a deepening of ties, ASEAN is the Zen master' (Banyan, 2016).

The lack of momentum in deepening regional integration within ASEAN largely stems from the protectionist stances of the majority of the member countries, with Singapore, perhaps, the only exception. Many ASEAN countries view other members as rivals in their pursuit of exporting to the global market or attracting FDI. Domestic political conflicts and the lack of strong and stable governments mean that the political leaders of many ASEAN countries look inward and lose their appetite for regional integration. Unless it squarely and urgently confronts the core problems of its integration project, ASEAN will not become a single market and a single production base, despite the vision of the AEC Blueprints. 


\section{The future of regional integration}

Formal regional integration in East Asia began with the formation of the AFTA in 1993. Later, in the 2000s, a number of bilateral FTAs were formed between ASEAN countries and North-East Asian countries, including the China-Thailand FTA and the Japan-Malaysia FTA. Then, ASEAN as a whole began to produce bilateral FTAs with the 'plus one' countries, beginning with China in 2005, Korea in 2007, Japan in 2008, Australia and New Zealand in 2010 and India, also in 2010.

Bilateral FTAs proliferate over broader FTAs because they are usually easier to negotiate and, thus, they are preferred by politicians seeking short-run successes. However, bilateral FTAs rarely align with the way in which business is actually conducted by firms because few buy and sell goods or services in just one market-even if that one market is huge (Elms, 2016b). Moreover, a set of bilateral FTAs does not provide an efficient production platform for multinational corporations in the regional production networks. This is because the ROOs do not allow for pairwise accumulation of regional value added. Consequently, a more seamless regional architecture is needed.

The next section considers the future of regional integration in East Asia by analysing the prospects for three regional integration initiatives: deeper integration in ASEAN, the fate of the TPP after the US presidential election and the future of RCEP. We do not discuss the proposal to form a Free Trade Area of the Asia-Pacific (FTAAP), previously proposed by Canada and again, more recently, by China, because we consider that if it is formed, it will be.

\section{Deeper integration in ASEAN}

ASEAN prides itself on being the hub of bilateral FTAs in East Asia. The concept of ASEAN centrality emphasises its role in facilitating economic integration in the region. However, so far economic integration among ASEAN members has focused on offering a more attractive package to multinational corporations seeking to operate in the region, rather than on creating stronger bonds between member economies (Fields, 2016). The negotiation of the TPP shows how fragile the idea of ASEAN centrality is, as the proposed arrangement did not include most ASEAN countries. 
For ASEAN to be central to East Asia's economic integration, two related conditions are required. First, integration among ASEAN economies must be significantly strengthened so that ASEAN becomes close to operating as a single market and production base. This requires ASEAN members to pool their sovereignty in certain areas; for example, the identification and reduction of NTBs in the case of trade in goods. Second, the institutions and organisations of ASEAN, specifically the ASEAN Secretariat, must be strengthened.

To strengthen its economic integration, ASEAN must aim to achieve critical targets and ignore trivial ones. In other words, ASEAN needs to be much more focused than it is now. The current ASEAN agenda is overly ambitious, considering its limited resources. The AEC Blueprint established 17 core elements and 176 priority actions, covering large subject areas, including the free flow of goods and capital, the movement of skilled labour, the development of small- and medium-sized enterprises and of infrastructure, capital market integration, equitable development and protection of intellectual property rights, to name just a few.

A sharper focus would help ASEAN to accelerate its liberalisation process, and deliver meaningful and tangible results, without depriving member countries, especially less developed ones, of their limited resources. This requires ASEAN to return to the core missions of an FTA: reducing barriers to trade and facilitating cross-border trade in goods and services and the movement of factors of production.

As tariff reduction is almost accomplished and ROOs are already relatively liberal, ASEAN should focus on reducing NTBs. In this regard, CCA needs to be empowered; although it has previously identified many NTMs used by ASEAN countries as non-transparent or discriminatory, it lacks the power to oblige these countries to abolish or improve them.

ASEAN should switch from its current positive-list approach to a negativelist approach in negotiating its service liberalisation, as suggested by Dee (2015). She also usefully suggested the inclusion of a ratchet mechanism, whereby any future domestic reforms would be automatically bound into AFAS schedules.

ASEAN should synchronise the commitments of Modes 3 and 4 in service liberalisation to implement the ideas of a single market and single production base as suggested by Fukunaga and Ishido (2015) and Dee (2015). Fukunaga and Ishido (2015) also recommended that the 
movement of professionals be extended to movement of people in the manufacturing sectors. They suggested the introduction of an ASEAN Business Travel Card, modelled after the APEC Business Travel Card, which would give cardholders a visa-free visit to other member countries for business purposes for two to three months.

In the longer term, ASEAN might consider taking steps towards the next phase of economic integration-that is, becoming a customs unionas proposed by Basu, Sen and Srivastava (2015), and Plummer (2006). Basu et al. proposed that a partial ASEAN Customs Union (ACU) could be formed among ASEAN-9 members, excluding Singapore, by cutting their common external tariffs to around 3 per cent, while Singapore would maintain its existing zero tariffs against non-members. They estimated that an ACU would generate sizeable welfare gains to ASEAN. However, this option is difficult to implement as ASEAN countries would have to unify their trade policies towards external trading partners. This includes each member country giving up the freedom to form FTAs on its own.

Stronger ASEAN institutions and organisations, specifically the ASEAN Secretariat, are prerequisites for deeper ASEAN integration. The ASEAN Secretariat is the only unit to coordinate, attend and summarise the burgeoning number of meetings. However, it remains largely underfunded, with less than US\$20 million in 2015. This tight budget results in stagnant salaries, job insecurity, high turnover and chronic underoccupancy (Nair, 2016).

However, the real challenge for ASEAN is not economic but political. Full national sovereignty and economic integration are incompatible. ${ }^{3}$ The success of the EU trade integration is based on pooled sovereignty. It should be emphasised that the idea of pooled sovereignty is not all or nothing in nature. When it commenced, the EU was a modest project. It had a few members and only one policy area for pooling sovereigntythe creation of a common market for coal and steel. Only gradually did it expand its membership and mission. Unless ASEAN countries are willing to increasingly pool their sovereignty, the AEC project will go nowhere and ASEAN will be no more than a 'talking shop'.

3 Dani Rodrik elaborated an idea along this line in his 'impossibility theorem' for the global economy. He argued that democracy, national sovereignty and global economic integration are mutually incompatible; we can combine any two of the three, but we can never have all three simultaneously and in full (Rodrik, 2002). 


\section{The collapse of the TPP}

From its commencement, the TPP was motivated by both economic and strategic considerations revolving around, but not limited to, the US role in international politics. From a strategic perspective, the TPP would enable the US to almost singlehandedly write the global trade rules in the twenty-first century. As former president Barack Obama succinctly stated:

The TPP means that America will write the rules of the road in the 21st century. When it comes to Asia, one of the world's fastest-growing regions, the rulebook is up for grabs. And if we don't pass this agreement-if America doesn't write those rules-then countries like China will. And that would only threaten American jobs and workers and undermine American leadership around the world. (White House, 2015)

For Japan, the TPP is an important element of Prime Minister Shinzo Abe's broad strategic goal of cementing Japan as the US's main Asian ally and a counterweight to China. Japan also intended to leverage the TPP negotiations to shake up its protected agricultural sector and reform the Japanese economy, as a crucial part of Abenomics's 'third arrow' of economic reforms. For Vietnam, the least developed country among the TPP members, the decision to enter into the agreement was also economically and strategically motivated. According to the World Bank's estimate, Vietnam would reap the largest benefits in terms of gross domestic product (GDP) growth from the TPP, with an estimated GDP increase of 10 per cent (World Bank, 2016). Strategically, Vietnam desires closer relations with the US amid its territorial tensions with China.

With these strategic and political goals in mind, the TPP negotiation needed to synchronise with internal political cycles, especially the US elections in 2016. As a result, many compromises were made at the last minute. Thus, although the TPP is frequently marketed as the 'gold standard' of trade agreements, it is much weaker than its supporters claim.

First, there are many carve outs and exceptions to the rules set in the main agreement. To give just one example, Malaysia has successfully negotiated to preserve its bumiputera agenda (initiatives in favour of indigenous Malays), obtain a minimum five-year grace period to reform state-owned enterprises and gain exemption for Khazanah, a national sovereign wealth fund, from investor-state dispute settlement provisions for two years after the deal comes into force. As noted by Nambiar (2016), 'anybody who thought that the TPP would trigger a domestic reform process in Malaysia will be disappointed'. 
Second, from an economic perspective, there are many welfare-decreasing provisions in the agreement. One of the most obvious examples is the notorious 'yarn forward' rule of origin imposed on garment products. The rule is likely to create trade and investment diversion away from lower cost non-member countries. Also highly controversial is the chapter on intellectual property rights. Many experts have pointed out that the TPP would jeopardise access to affordable medicine for the poor, and raise the prices of agricultural chemicals and seeds in the member countries because of its lengthy patent protection and data exclusivity provisions. In addition, the TPP grants extraordinarily long copyright protection-to a minimum specified as the term of the creator's life plus 70 years. Many leading economists have argued that such a long protection term provides marginally little benefit to creators but generates high costs to society. ${ }^{4}$

Despite the successful conclusion of the negotiation, the ratification of the TPP has been uncertain from the beginning, particularly in the US. According to the concluded text, the TPP will become effective if either 1) all the member countries complete their own domestic ratification procedures; or 2) at least six countries, which have at least 85 per cent of the total GDP of the original members, ratify it within two years.

Many member countries have opted to delay TPP ratification, waiting for the US Congress to do so first. This was rational, as ratification by the US is essential for the TPP to take effect-the US alone constitutes about 60 per cent of TPP members' aggregate GDP.

Lawmakers from both major political parties in the US criticised the deal. The complaints raised by members of Congress were concentrated around three major issues: the shorter period of data protection for biologic medicines than that provided under US law, the exclusion of financial services from the prohibition on data localisation measures under the electronic commerce chapter and the exclusion of tobacco products from the benefits of investor-state dispute settlement (Lincicome \& Picone, 2016). There was also broader concern about how to ensure that other TPP members would fully implement the commitments.

4 In total, 17 prominent economists, including five Nobel Prize winners (George Akerlof, Kenneth Arrow, James Buchanan, Ronald Coase and Milton Friedman), submitted an amicus brief opposing the US bill from which the TPP borrows its text when it was challenged in court in 2002 (see cyber. harvard.edu/openlaw/eldredvashcroft/supct/amici/economists.pdf). 
The prospect of TPP ratification became bleaker during both major parties' primary elections and the subsequent general US presidential electoral campaign. Donald Trump outrageously claimed that the TPP is a 'rape of [the US]', despite the fact that the entire text was largely drafted by the US team. In an atmosphere of heightened protectionism, Hillary Clinton changed her stance to oppose the deal. Senate Majority Leader Mitch McConnell and House Speaker Paul Ryan said that they would not schedule a vote for the ratification of the TPP in the lame duck session and insisted that several provisions of the agreement be renegotiated.

After the presidential election, Donald Trump made it clear that he would withdraw from the TPP and indicated his preference to enter into bilateral trade deals instead. This shift of position seriously undermines the US's negotiation credibility, as the TPP text has already accommodated US demands more than those of other countries. A study by Allee and Lugg (2016) found that, out of the 74 previous trade agreements that TPP members have signed since 1995, the text of the TPP most resembles that of existing US FTAs. This is particularly true in chapters that are of greatest concern to US political leaders, such as the investment chapter, where nearly half the 16,000-word text was lifted directly from past US FTAs.

The collapse of the TPP would certainly disappoint the governments of the negotiating partners, including Japan, Australia and Vietnam, as they have not only put in significant efforts to negotiate the draft agreement but also taken the political heat from interest groups in their countries. More importantly, it is a big setback for regional integration for two reasons. First, an attempt to create a mega-FTA that integrates countries in the Pacific rims has not borne fruit. Second, the momentum for concluding a high-standard RCEP may not be maintained without the ratification of the TPP.

\section{The future of RCEP}

The idea of a free trade area covering the ASEAN+6 countries was first proposed by Japan. With the TPP under negotiation, China, which initially pushed for the ASEAN+3 FTA, agreed to the ASEAN+6 deal, which later became RCEP. Proposed by Japan, and later endorsed by India, ASEAN was assigned to the 'driver's seat'. This reiterates the idea of ASEAN centrality in the emerging regional economic architecture. 
Unlike the US-centric TPP, RCEP is Asian-centric. Even though RCEP is more populous, its aggregate GDP (US\$22.6 trillion in 2015) is smaller than that of the TPP (US\$27.5 trillion). However, the total economic size of RCEP is likely to overtake that of the TPP within the next 15 years, assuming the current growth rates of their respective member countries. While the TPP aimed at setting a 'gold standard' for international trade agreements, RCEP has never aimed to do so. It was designed from the beginning to be more accommodating and to focus on traditional trade policies.

At the launch of RCEP negotiations in November 2012, the leaders of ASEAN and its FTA partners endorsed the 'Guiding Principles and Objectives for Negotiating the Regional Comprehensive Economic Partnership'. According to the document, RCEP would encompass trade in goods and services, economic and technical issues, intellectual property and investments, and dispute settlement mechanisms. It also aims to improve on the existing ASEAN+1 FTAs in terms of breadth and depth, while recognising the individual and diverse circumstances of the participating countries. The guiding principles document explicitly includes a 'provision for special and differential treatment plus additional flexibility' for participating countries. RCEP reached its 15 th round of negotiations in October 2016. Although the negotiation details are kept secret, progress has reportedly been very slow so far, and the 2016 end-ofyear deadline for conclusion has already been missed.

Elms (2016c) suggested that there are four potential outcomes for RCEP. First, a complete failure of negotiations. This would be deeply problematic, but not entirely unexpected. Second, RCEP could conclude in relative short order, but only if leaders fudged issues and left details of the deal to be worked out by officials in the 'legal scrub' or 'translation'. This would be risky if the agreement is not sufficiently close to conclusion. Third, RCEP could conclude on schedule with a 'built-in agenda' to negotiate unsettled issues. However, ASEAN's experience of using built-in agendas indicates that the progress afterwards could be extremely slow. Fourth, RCEP could announce an 'early harvest' and keep negotiating. While this is not ideal for many dialogue partners, Elms considered that a small comprehensive package that does not dilute the interest of most members to maintain talks might be worthwhile. 
We concur with Elms's (2016c) conclusion. Ultimately, for RCEP to be meaningful and relevant, it has to deliver significant additional benefits to all participants compared with the current ASEAN+1 FTAs. To add significant benefits, RCEP should strive for deeper regional integration and trade facilitation. It can emulate certain parts of the TPP and avoid provisions that are clearly welfare decreasing.

First, RCEP should mandate the elimination of all tariffs and other restrictions on trade in goods for virtually all goods, with few exceptions or carve outs. ROOs should aim at achieving an 'upward harmonisation' of those ROOs of existing ASEAN+1 FTAs; that is, RCEP should have the most liberal ROOs per product among ASEAN and all ASEAN+1 FTAs, as suggested by Medalla (2015). In addition, it should avoid using restrictive product-specific rules, such as the yarn forward rules adopted in the TPP. With less than upwardly harmonised ROOs, RCEP would just add another layer of rules and become irrelevant.

Second, RCEP should adopt a negative-list approach in negotiating service liberalisation and a ratchet mechanism and it should allow linkages between the commitments in Modes 3 and 4.

Third, it should refrain from including the clearly welfare-decreasing provisions embedded in the TPP text. These include the many provisions that grant overly stringent intellectual property rights protection, mentioned in the previous subsection. In addition, provisions on issues not directly related to trade should also be avoided. These include provisions related to currency manipulation (see Gupta, 2015) and cyber security (Baker, 2015).

The real obstacle to concluding a high-quality RCEP is the politics of protectionism. To give just one example, India is reportedly unwilling to reduce its tariff rates. At one point in the negotiation, it had proposed a three-tier schedule of tariff liberalisation, apparently to block imports of steel, aluminium and chemical products from China (Pailit, 2016). India's protectionism is also evidenced by the fact that it is one the most frequent users of anti-dumping and safeguard measures in the world.

In this context, RCEP's most important problem is that no one country is really in charge. To make RCEP meaningful and relevant, negotiating countries that have liberal trade policies, including Australia, New Zealand, Singapore and Japan, should take the leadership role. RCEP should aim at setting an ambitious target of deep economic integration, 
with a reasonable transition period for less developed countries. For example, a limited number of provisions may become binding to a less developed country only when its income per capita reaches a pre-specified threshold.

Learning from the TPP's ratification predicaments, RCEP may allow a lower threshold to become effective among the ratified members. This would prevent the failure of a few countries to ratify from sabotaging the whole agreement.

\section{Implications for Thailand}

This final section of the chapter will draw out some policy implications for Thailand, based on the developments in economic integration in East Asia discussed in the chapter. It is hoped that the implications analysed here will be useful to other developing countries in ASEAN.

The objectives of trade policy should not be limited to increasing a country's export opportunities. Rather, trade policy should aim at stimulating and facilitating domestic reform to improve the country's productivity and competitiveness in the long run. With the aim of increasing export opportunities through preferential treatment, Thailand was very active in negotiating FTAs with its trading partners during the 2000s. As a result, the ratio of Thailand's exports to FTA partner countries compared to its total exports rose rapidly from 19.3 per cent in 2001 to 53.5 per cent in 2010 .

Thailand launched FTA negotiations with the US in 2004, the European Free Trade Association in 2005 and the EU in 2013, but none of these negotiations was successfully concluded. The negotiation with the US was officially terminated after eight rounds of negotiations, whereas those with the European Free Trade Association and the EU have been suspended.

Since 2010, Thailand has not secured any new FTAs with its major trading partners. The most recent effective FTA (implemented in 2012) was with Peru, which is a minor trading partner, with a trade share of just 0.16 per cent for Thailand. As a result, the share of exports to FTA partner countries has organically increased from the 2010 level of 53.5 per cent to 56 per cent by 2014. Thailand's FTAs with Turkey and Pakistan, if successfully concluded, would have a marginal effect in terms of increasing Thailand's market access opportunities. 
Unlike Japan and Australia, both of which used trade agreements as a catalyst for structural reforms, Thailand has never aimed at facilitating domestic reform through its FTA efforts. According to the Thai Department of Trade Negotiations, the strategic goals of Thailand's FTA initiatives are to expand exports, seek inbound and outbound investment opportunities, seek external resources to cut production costs, and develop human resources and technologies. Regrettably, the goal of using trade policy for structural reform is missing in Thailand. Further, the Thai negotiation team aims to ensure that no legislative acts need to be amended as a result of the trade negotiations. This reflects the broader mindset of the Thai government, which appears to believe that Thailand can upgrade itself into a high-income country-through increasing goods and services exports, and attracting FDI and investment in infrastructure-without facing the difficulties of structurally reforming the economy. The government initiative closest to structural reform is its effort to facilitate the ease of doing business by improving the country's standing in the World Bank annual ranking. However, deregulation is just one part of the real structural reform required.

This mindset is reflected in the Twelfth Economic and Social Development Plan (2017-21) approved by the Thai cabinet. A key pillar of the plan is to promote economic growth through regional and international cooperation. In particular, the plan sets an average growth target of 5 per cent per year throughout the 10 -year period. This would be achieved by increasing labour productivity and total factor productivity, each at 2.5 per cent per year, across the manufacturing, agricultural and service sectors.

With regard to trade strategy, the plan aims to expand trade and investment cooperation with 'like-minded' countries to:

- increase market access opportunities for Thai products and services

- develop physical connectivity within the region

- promote Thailand as an investment destination by developing border special economic zones

- promote outward investment of Thai businesses

- form trade and investment partnerships with other countries in the region. 
The plan does not explicitly mention trade liberalisation as a policy instrument, nor any structural reforms of the agricultural and service sectors.

The service sector constitutes roughly half of Thailand's GDP and labour force. However, its productivity level is only half that of manufacturing. The agricultural sector, which constitutes 35 per cent of the country's labour force and 12 per cent of GDP, has an even lower productivity level. The low level of productivity in both sectors is partly the result of limited competition in the sectors, arising from Thailand's restrictive foreign investment regime. The regime is most restrictive in the agricultural sectors and, to a lesser extent, in the service sectors (Nikomborirak, 2013).

For Thailand to escape the 'middle-income trap', it needs to refocus its development priorities towards reforming its economy in general and increasing productivity levels in the service and the agricultural sectors, in particular. With only 16 per cent of its labour force working in factories, Thailand can no longer rely on its export-oriented manufacturing sector as its sole economic driver in a global economy characterised by lower growth. Thailand needs to shift towards promoting domestic demand, which requires policies that can help lift the income of the masses.

The first-best option to reform the Thai economy is to unilaterally liberalise its market by amending existing laws and regulations that prevent the country from having more competition and better resource allocation. However, such reforms are usually difficult to carry out because of opposition from interest groups that stand to lose from foreign competition. It is in this context that regional integration is critical for the future of the Thai economy.

With the collapse of the TPP, Thailand should actively contribute in the negotiation to make RCEP meaningful by pushing it to a high standard along the lines proposed in the previous section. Ultimately, Thailand should realise that it is no longer possible to propel itself to high-income status by pursuing a narrow trade policy agenda without major economic reforms. 


\section{References}

Allee, T. \& Lugg, A. (2016). Who wrote the rules for the Trans-Pacific Partnership?, Research \& Politics, 3(3), 1-9.

Almekinders, G., Fukuda, S., Mourmouras, A., Zhou, J. \& Zhou, Y. (2015). ASEAN financial integration. IMF Working Paper WP/15/34. Retrieved 4 January 2017 from: www.imf.org/external/pubs/ft/wp/ 2015/wp1534.pdf

Asian Development Bank. (2013). The road to ASEAN financial integration: A combined study on assessing the financial landscape and formulating milestones for monetary and financial integration in ASEAN. Retrieved 4 January 2017 from: www.adb.org/sites/default/ files/publication/30202/road-asean-financial-integration.pdf

Association of Southeast Asian Nations Secretariat (ASEAN). (2015a). ASEAN economic community blueprint 2025. Retrieved 16 October 2016 from: www.asean.org/storage/images/2015/November/aec-page/ AEC-Blueprint-2025-FINAL.pdf

Association of Southeast Asian Nations Secretariat (ASEAN). (2015b). A blueprint for growth-ASEAN economic community 2015: Progress and key achievements. Retrieved 16 October 2016 from: www.asean. org/storage/images/2015/November/aec-page/AEC-2015-Progressand-Key-Achievements.pdf

Baker, S. (2015, 6 November). Cybersecurity and the TPP. The Washington Post. Retrieved from: www.washingtonpost.com/news/ volokh-conspiracy/wp/2015/11/06/cybersecurity-and-the-tpp/?utm_ term $=.62 \mathrm{dbb} 01743 \mathrm{ac}$.

Banyan. (2016, 3 September). Agreeing to agree. The Economist. Retrieved from: www.economist.com/news/asia/21706264-south-eastasian-summitry-apogee-form-over-substance-may-be-no-bad-thingagreeing.

Basu Das, S., Sen, R. \& Srivastava, S. (2015). AEC vision post-2015: Is an ASEAN customs union feasible? ISEAS Economics Working Paper No. 2015-1. Retrieved from: www.iseas.edu.sg/images/centres/asc/ pdf/EWP20151.pdf 
Bauer, M., Makiyama, H. L., van der Marel, E. \& Verschelde, B. (2014). The costs of data localisation: a friendly fire on economic recovery. ECIPE Occasional Paper No. 3/2014. Retrieved 31 October 2016 from: www.ecipe.org/app/uploads/2014/12/OCC32014_1.pdf

Cadot, O. \& Ing, L. Y. (2016). How restrictive are ASEAN's ROO? Asian Economic Papers, 15(3), 115-34. doi.org/10.1162/ASEP_a_00461

Dee, P. (2015). Monitoring the implementation of services trade reform towards an ASEAN economic community. ERIA Discussion Paper Series 2015-44. Jakarta: Economic Research Institute for ASEAN and East Asia.

Economic Research Institute for ASEAN and East Asia (ERIA). (2012). Mid-term review of the implementation of AEC Blueprint. Jakarta: Economic Research Institute for ASEAN and East Asia.

Elms, D. (2016a, 14 September). ASEAN: Still more process than destination. Asian Trade Centre Talking Trade Blog. Retrieved 10 October 2016 from: www.asiantradecentre.org/talkingtrade// asean-still-more-process-than-destination

Elms, D. (2016b, 7 September). TPP collapse? Plan B for everybody else. Asian Trade Centre Talking Trade Blog. Retrieved 10 October 2016 from: www.asiantradecentre.org/talkingtrade//tpp-plan-b-foreverybody-else

Elms, D. (2016c, 19 July). RCEP: Status update. Asian Trade Centre Talking Trade Blog. Retrieved 12 October 2016 from: www.asiantrade centre.org/talkingtrade//rcep-status-update

Fields, S. (2016). Trouble ahead for ASEAN. Berkeley APEC Study Center Newsletter, 18 Winter 2015/16. Retrieved from: basc.berkeley.edu/wpcontent/uploads/2016/04/BASC-Newsletter-Winter-15_16.pdf

Fukunaga, Y. (2015). Assessing the progress of ASEAN MRAs on professional services. ERIA Discussion Paper Series. Jakarta: Economic Research Institute for ASEAN and East Asia.

Fukunaga, Y. \& Ishido, H. (2015, March). Values and limitations of the ASEAN agreement on the movement of natural persons. ERIA Discussion Paper Series 2015-20. Jakarta: Economic Research Institute for ASEAN and East Asia. 
Gupta, S. (2015, 17 May). Keep currency clauses out of the global trading system. East Asia Forum. Retrieved 16 October 2016 from: www.eastasiaforum.org/2015/05/17/keep-currency-clauses-out-ofthe-global-trading-system/

Ing, L. Y., de Cordoba, S. F. \& Cadot, O. (2016). Non-tariff measures in ASEAN. ERIA Discussion Paper Series. Jakarta: ERIA and UNCTAD.

Intal, P. (2015a, May). AEC blueprint implementation performance and challenges: Trade facilitation. ERIA Discussion Paper Series 2015-41. Jakarta: Economic Research Institute for ASEAN and East Asia.

Intal, P. (2015b, April). AEC blueprint implementation performance and challenges: Investment liberalization. ERIA Discussion Paper Series 2015-32. Jakarta: Economic Research Institute for ASEAN and East Asia.

Kausikan, B. (2016, 1 September). Never mind territorial spatsASEAN's priorities are economic. Nikkei Asian Review. Retrieved from: asia.nikkei.com/magazine/20160901-ASEAN-THE-GREATPUZZLE/On-the-Cover/Never-mind-territorial-spats-ASEAN-spriorities-are-economic

Lincicome, S. \& Picone, B. (2016, May). Evaluating the Trans-Pacific Partnership. White \& Case LLP. Retrieved 30 October 2016 from: www. whitecase.com/publications/alert/evaluating-trans-pacific-partnership

McKinsey Global Institute. (2014). Southeast Asia at the crossroads: Three paths to prosperity. McKinsey \& Company. Retrieved from: www.mckinsey.com/global-themes/asia-pacific/three-paths-tosustained-economic-growth-in-southeast-asia

Medalla, E. M. (2015). Towards an enabling set of rules of origin for the Regional Comprehensive Economic Partnership. In Ing, L. Y. (Ed.), East Asian integration (pp. 93-121). Jakarta, Indonesia: Economic Research Institute for ASEAN and East Asia.

Menon, J. \& Melendez, A. C. (2015, May). Realizing an ASEAN economic community: Progress and remaining challenges. $A D B$ Economics Working Paper Series No. 432. Retrieved from: www.adb. org/publications/realizing-asean-economic-community-progress-andremaining-challenges 
Nair, D. (2016, February). A strong secretariat, a strong ASEAN? A re-evaluation. ISEAS Perspective Issue 2016 No. 8, Singapore: Institute of Southeast Asian Studies.

Nambiar, S. (2016, 13 February). Is the TPP really a leap forward for Malaysia? East Asia Forum. Retrieved from: www.eastasiaforum. org/2016/02/13/is-the-tpp-really-a-leap-forward-for-malaysia/

Narjoko, D. (2015, May). AEC blueprint implementation performance and challenges: Services liberalization. ERIA Discussion Paper Series 2015-39. Jakarta: Economic Research Institute for ASEAN and East Asia.

Nikomborirak, D. (2013, June). Service liberalization under the ASEAN economic community: Myths and reality, opportunities and challenges. TDRI Quarterly Review, 28(2) 3-9.

Organisation for Economic Co-operation and Development (OECD). (2016). Economic outlook for Southeast Asia, China and India 2016: Enhancing regional ties. OECD Publishing. doi.org/10.1787/saeo2016-en

Pailit, A. (2016, 30 September). India inches towards liberalisation at RCEP. East Asia Forum. Retrieved 16 October 2016 from: www. eastasiaforum.org/2016/09/30/india-inches-towards-liberalisation-atrcep/

Plummer, M. (2006, February). An ASEAN customs union? Journal of Asian Economics, 17(5). doi.org/10.1016/j.asieco.2006.08.013

Rodrik, D. (2002). Feasible globalizations. Unpublished research paper. Retrieved 31 October 2016 from: drodrik.scholar.harvard.edu/files/ dani-rodrik/files/feasible-globalizations.pdf

Schott, J. J. \& Jung, E. (2015). An assessment of the Korea-China free trade agreement. Policy Brief Number PB15-24. Peterson Institute for International Economics. Retrieved from: piie.com/publications/ policy-briefs/assessment-korea-china-free-trade-agreement 
Tan, C. K. (2016, 1 September). CIMB chief calls on the private sector to move integration forward. Nikkei Asian Review. Retrieved from: asia. nikkei.com/magazine/20160901-ASEAN-THE-GREAT-PUZZLE/ On-the-Cover/CIMB-chief-calls-on-the-private-sector-to-moveintegration-forward

Thailand Development Research Institute (TDRI). (2013). Increasing the competitiveness of Thai industries under Thailand's international economic policy. Final report submitted to the Office of Industrial Economics, Ministry of Industry (in Thai).

White House. (2015). Here's the deal: The Trans-Pacific Partnership. Retrieved 1 October 2016 from: www.whitehouse.gov/blog/2015/ 11/06/heres-deal-trans-pacific-partnership

World Bank. (2011). World Bank services trade restrictions (database). Washington, DC: World Bank. Retrieved from: data.worldbank.org/ data-catalog/services-trade-restrictions.

World Bank. (2013). ASEAN integration monitoring report. Washington, DC: World Bank. Retrieved 15 October 2016 from: documents. worldbank.org/curated/en/915081468234873037/pdf/ 839140 WP0P14480Box0382116B00PUBLIC0.pdf

World Bank. (2016, January). Potential Macroeconomic implications of the Trans-Pacific Partnership. Global Economic Prospects. Washington, DC: World Bank.

World Economic Forum. (2013). Enabling trade valuing growth opportunities. Retrieved 16 October 2016 from: www3.weforum.org/ docs/WEF_SCT_EnablingTrade_Report_2013.pdf 
This text is taken from Asian Economic Integration in an Era of Global Uncertainty, edited by Shiro Armstrong and Tom Westland, published 2018 by ANU Press, The Australian National University, Canberra, Australia. 